\title{
AN INVESTIGATION OF THE VELAR NASAL IN BADINI KURDISH DIALECT
}

\author{
Saeed Adrees Saeed and Laureen Ibrahim Naser* \\ Dept. of English Language, College of Basic Education, University of Duhok, Kurdistan Region, Iraq. \\ Received: 05. 2017 / Accepted: 09. 2017 / Published: 12. 2017 \\ https://doi.org/10.26436/2017.5.4.512
}

\begin{abstract}
:
The velar nasal, also called "Engma" or "Angma", can be found in the phonologicalinventories of many languages across the world. Kurdish researchers vary in their opinions as to whether this sound is listed among the inventory of Kurdish language phonemes or not. Some researchers have tackled this case in Sorani Kurdish but research in Badini is scarce in this area. In this paper we aim to investigate the velar nasal /N/ in Badini Kurdish, which is a very controversial topic. The paperaims to answer the question as to whether it can be considered as a phoneme or it is just an allophonic realization of the alveolar nasal /n/ when followed by the voiced velar stop/g/. This is done through providing examples that have the combination of $(\mathrm{n}+\mathrm{g})$ which have a possible occurrence of the velar nasal. These examples are first analyzed articulatory in terms of some phonological processes such as assimilation, morpheme affixation, and syllabification. They are then analyzed acoustically by contrasting the pairs and searching for nasal bands using Praat. After analyzing both articulatory and acoustic data, it was concluded that the velar nasal can be found in Badini Kurdish but only as an allophone of the alveolar nasal which is the result of certain phonological rules such as assimilation and co-articulation. They are in free variation and couldn't change the meaning. So, we can't consider it as a distinct phoneme in this dialect.
\end{abstract}

KEYWORDS: Velar nasal, assimilation, syllabification, Badini Kurdish, acoustic analysis.

\section{INTRODUCTION}

Nasals can be classified according to their place and manner of articulation. When the nasal consonants are produced the soft palate (velum) is lowered so that the nasal cavity is open while the oral tract is blocked. This shows the manner in which nasals are articulated. We can also describe nasals through their place of articulation which can be bilabial, alveolar, or velar. This refers to the place in which the constriction happens. If we consider the Engma, we can classify it as a velar nasal stop. When this sound is produced the velum is lowered to open the nasal cavity to create a nasal sound and at the same time to form a stricture for the velar nasal. The burst of the plosive is not audible because air pressure is released through the open nasal cavity. What is worth mentioning is that the vocal folds vibrate during the production of this sound. So the velar nasal is a voiced sound.

In a study, which discusses the presence versus absence of the velar nasal in world languages, Anderson (2008) bases his discussions on a database of 512 diverse languages across the world. Unfortunately, the Kurdish language was not included. No clear answer has been given in the literature as to whether this phoneme is found in Kurdish or not, especially in Badini dialect, which will be the focus of this study. Not only research in this area is scarce, but also what is found is based on mere observations.

After reviewing the relevant literature, data were gathered for the purpose of the articulatory and acoustic analyses which are conducted in this research.

\section{AIMS}

There has been little significant effort in describing the features of Kurdish language. Many gaps appear when searching for certain issues in the literature. We aim to make a contribution to the Kurdish language through this research. One of the controversial issues is the question of whether the velar nasal sound/ $\mathrm{N} /$ is phonemic in Badini Kurdish or not. In order to decide whether this sound is regarded as a distinct phoneme or not, we need to provide both articulatory and acoustic evidence, which is the aim and focus of our research.

\section{RELATED LITERATURE}

Looking through the literature, we can find that Kurdish researchers differ in their opinion between those who assert and those who deny the existence of the velar nasal in Kurdish language.Wais (1984:61), for example shows some instances of the velar nasal $/ \mathrm{N} /$ in some Kurdish words with the combination of $(n+g)$ such as the following:

$\begin{array}{lll}\text { "lang" } & / \lambda \Theta \mathrm{N} / & \text { (lame) } \\ \text { "mang" } & / \mu \Theta \mathrm{N} / & \text { (month) } \\ \text { "tang" } & / \tau \Theta \mathrm{N} / & \text { (tight) }\end{array}$

Wais (1984) refers to the existence of the velar nasal in these examples but asserts that it is not a phoneme in any of the examples but it is only an allophonic realization of the phoneme $/ \mathrm{n} /$ in each case. This means that the velar nasal and the alveolar nasal are in free variation without affecting the meaning. He bases his generalization on articulatory factors. In the combination of $(\mathrm{n}+\mathrm{g})$, the velum cannot wholly synchronize its movement between the lowering position for the nasal $/ \mathrm{n} /$ and the closure position for the $/ \mathrm{g} /$. This creates 
some sort of co-articulation between the two sounds producing the continuant $/ \mathrm{N} /$.

Fatah (1982) supports the view that the velar and alveolar nasals are only allophonic realizations in Kurdish due to certain phonetic rules. He adds that when two voiced sounds succeed each other or are articulated close to each other, the later affects the former and the result is some sort of coarticulation between the two sounds. This case happens when the sound $/ \mathrm{n} /$ is followed by $/ \mathrm{g} /$. The co-articulation between them is what leads to the production of an allophone which is usually confused with the velar nasal/N/.

MacKenzie (1961) adds that when the velar nasal/N/ is followed by a velar plosive it may be considered as an allophone of $/ \mathrm{v} /$.

Baban (2005) also argues that this sound cannot be considered as one of the Kurdish phonemes. He adds that instances of this allophone can be found in the spoken language of some Kurdish accents (without mentioning which one exactly). They can be found in the combination of $(n+d)$ especially in connected speech:

$\begin{array}{llc}\text { "chand" } & / \tau \Sigma \Theta \mathrm{N} / & \text { (how many) } \\ \text { "mand" } & / \mu \Theta \mathrm{N} / & \text { (ceiling wood) } \\ \text { "pand" } & / \pi \Theta \mathrm{N} / & \text { (proverb) } \\ \text { "awanda" } & / \Theta \omega \Theta \mathrm{N} \Theta / & \text { (that) }\end{array}$

Other researchers like Ameen (2004), Marif (1976), and Thackston (2006) share the same view. They list the classification of Kurdish sounds without mentioning the velar nasal among these sounds.

On the other hand, Hawramany (1981:77) asserts the existence of the velar nasal as one of the phonemes of the Kurdish language since it causes a change in meaning between the following words:

$\begin{array}{lll}\text { "ban" } & / \beta \alpha\rceil \nu / & \text { (roof) } \\ \text { "bang" } & / \beta \alpha\rceil \mathrm{N} / & \text { (call) }\end{array}$

He brings other examples which include this sound such as:

$\begin{array}{lll}\text { "sangin" } & / \sigma \Theta N I v / & \text { (worthy) } \\ \text { "dang" } & / \delta \Theta N / & \text { (sound) } \\ \text { "jangawar" } & / \delta \mathrm{Z} \Theta \mathrm{NI} \omega \Theta \rho / & \text { (warrior) } \\ \text { "rang" } & / \rho \Theta \mathrm{N} / & \text { (color) }\end{array}$

He also adds that in Sulaimany dialect, the velar nasal/N/is heard in the combination of $(\mathrm{n}+\mathrm{z})$ in some numbers, which is also referred to by MacKenzie (1961), such as:

$\begin{array}{ll}\text { "panzda"/ } / \pi \alpha\rceil \mathrm{N} \zeta \Theta / & \text { (fifteen) } \\ \text { "yanzda"/ } \psi \alpha\rceil \mathrm{N} \zeta \Theta / & \text { (eleven) }\end{array}$

Ali (2007) also states that the velar nasal is considered as a phoneme in Sulaimany dialect. He supports his view with the Kurdish rule that states that when a morpheme is added to a syllable or a word, the last phoneme of the syllable or word is assigned to the morpheme to form another syllable, like this example

dar $+\mathrm{a}=$ da.ra $\quad$ (tree)

If we followed the same rule, when a sound ending in/ $\mathrm{N} /$ is followed by a morpheme, then the sound should join the morpheme in a separate syllable without dividing it to two sounds $(\mathrm{n}+\mathrm{g}$ ) and only moving $/ \mathrm{g} /$ to the added morpheme. The result is the following syllabification:

Hang (bee) + ek $($ one $)=$ hangek (one bee)

$/ \eta \Theta N / \quad / \varepsilon \kappa / \quad / \eta \Theta . N \varepsilon \kappa /$

This syllabification is not acceptable since there are phonological rules that apply to syllable edges. In all languages, syllable edges correspond with word/utterance edges (Blevins, 1996: 208). Gimson (1970: 239) states that in order to be able to specify the phonological syllable boundary, it is important to have knowledge of the possible word initial and final sequences. In other words what is acceptable in word initial/ final positions is also acceptable in syllable initial/final positions. This principle is called the legality principle proposed by Treiman and Zukowski (1990) cited in AlBamerni (2004: 114). For example, a word like 'picnic' is syllabified as $/ \pi \mathrm{I} . \kappa v \mathrm{I} \kappa /$ according to the Maximal Onset Principle. This syllabification violates the legality principle since the sequence ' $\mathrm{kn}$ ' is not accepted word initially. So the word 'picnic' is re-syllabified as/ $\pi \mathrm{I} \kappa . v \mathrm{I} \kappa / . \mathrm{If}$ we look at the previous example, "hangek" (one bee) $/ \eta \Theta . N \varepsilon \kappa /$, the second syllable starts with the velar nasal $/ \mathrm{N} /$ which never comes initially in Kurdish words. So according to the legality principle this syllabification is not acceptable.

In a comparison of the sound systems of Sorani and Kurmanji dialects of Kurdish, Azadpour and Mohammadi (2014) also include the velar nasal as a basic phoneme in both dialects, based on personal observation, and mention examples like the following.

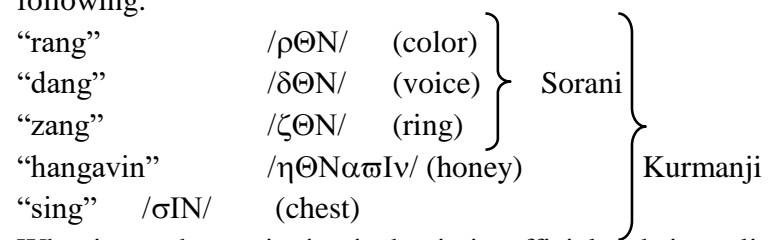

What is worth mentioning is that in its official website online, the Kurdish Academy of Language lists this velar nasal phoneme among the main Kurdish consonants which are described as unified Kurdish Phonemes, without even giving examples.

The question still remains unanswered. Some of the generalizations mentioned above are not supported with evidence. At the same time those which are justified are only based on articulatory grounds without further investigation of the scientific features of the sound in question.

\section{METHODOLOGY}

\subsection{Stimuli (Target words)}

Preparing a list of example pairs with certain letter combinations, like $/ \mathrm{n} /$ preceding $/ \mathrm{g} /$, which have a possible chance for the occurrence of the velar nasal/ $\mathrm{N} /$ in contast with $/ \mathrm{n} /$. The following are two example pairs:

$\begin{array}{ll}\text { dan } & \text { dang } \\ / \delta \Theta v / & / \delta \Theta N \gamma / \\ \text { (potter) } & \text { (sound) } \\ \text { ban } & \text { bang } \\ / \beta \alpha\rceil v / & / \beta \alpha\rceil \mathrm{N} \gamma / \\ \text { (roof) } & \text { (call) }\end{array}$

See appendix (B) for more examples from the reading list.

\subsection{Subjects}

Selecting (5) monolingual Kurdish native speakers for reading the lists of words in a production task. These subjects are from Duhok city which speak Badini Kurdish. They are aged 20-40. Each speaker reads the list three times to insure reliability of results.

\subsection{Procedures}

These readings have been recorded on a PC to be analyzed acoustically using Praat which is a sound wave-analyzer. 


\section{RESULTS}

\subsection{Articulatory Analysis}

One of the controversial issues in Badini Kurdish is the question of whether the velar nasal sound/ $\mathrm{N} /$ is phonemic or not. In order to prove this we need to provide minimal pairs which differ only in this sound to conclude that they are phonemic and they could change meaning. After searching we found that it was not possible to provide minimal pairs because they do not exist in Badini Kurdish. As an alternative, we prepared a list of example words with certain letter combinations $(\mathrm{n}+\mathrm{g})($ see appendix $\mathrm{A})$, thathave a possible chance for the occurrence of the velar nasal/ $\mathrm{N} /, \sigma \iota \iota \lambda \lambda \alpha \rho \tau \mathrm{O}$ samples which produce this sound in other languages such as English in words such as (thing, hang, singing, ...etc). We aim to apply some phonological processes such as assimilation, morpheme affixation, and syllabification to see whether this sound can be seen as a distinct phoneme or not.

If we look at the words in appendix (A), we can see that they involve a phonological rule of place assimilation. Place assimilation usually occurs in consonant clusters. One of the consonants takes the place of articulation of the neighboring consonant. This phonological rule of place assimilation is also applied when an alveolar nasal is followed by a voiced velar stop. For example, in a word like 'dang' $/ \delta \Theta N \gamma /$, we can see a case of assimilation in which the alveolar nasal /n/ changes its place of articulation to be similar to the following voiced velar stop $/ \mathrm{g} /$, and the result is that a velar nasal $/ \mathrm{N} /$ is produced instead of the alveolar nasal $/ \mathrm{n} /$, which are both allophones in free variation. Below is a list of more examples:

$\begin{array}{lll}\text { dang } & / \delta \Theta N \gamma / & \text { (sound) } \\ \text { bang } & / \beta \alpha\rceil \mathrm{N} \gamma / & \text { (call) } \\ \text { tang } & / \tau \geq \Theta \mathrm{N} \gamma / & \text { (tight) }\end{array}$

We cannot apply the same rule to alveolar nasals followed by voiceless velar stops because they differ in voicing.

If we take similar examples and we add some morphemes to them shown below:

$\begin{array}{ll}\text { dang (sound) }+ \text { dan }= & \text { dangdan (voting) } \\ / \delta \Theta N \gamma / \quad / \delta \alpha\rceil_{V} / & / \delta \Theta N . \delta \alpha\rceil_{V} / \\ \text { bang (call) }+ \text { vadan }= & \text { bangvadan }\end{array}$

bang (call) + vadan $=\quad$ bangvadan (calling)/ $\left.\left.\beta \alpha\rceil \mathrm{N} \gamma / \quad / \varpi \Theta \delta \alpha\rceil_{V} / \quad / \beta \alpha\right\rceil \mathrm{N} . \varpi \Theta . \delta \alpha\right\rceil_{\nu} /$

We can see that the sounds $/ \mathrm{n} /$ and $/ \mathrm{g} /$ have both co-articulated and the result is the production of the velar nasal instead of both sounds. This is probably caused because in Kurdish clusters of three concessive consonants are not possible. So, the production of the velar nasal is the result of the simplification of the consonant clusters.

In Kurdish language, when we syllabify a word with an added morpheme (suffix), the last sound of the word is assigned to the syllable of the added morpheme. So, if we examine the following words with the added morphemes, we can have significant results about what we are searching for.

rang $($ color $)+$ een $=$ ran.geen $($ colorfull $)$

$\left./ \rho \Theta N \gamma / /\rceil_{v} / / \rho \Theta v . \gamma \tau\right\rceil_{v} /$

zang (ring) + il = zan.gil(ringer)

$\mid \zeta \Theta \mathrm{N} \gamma / \quad / \mathrm{I} \lambda / \quad / \zeta \Theta v \cdot \gamma \mathrm{I} \lambda /$

greng(important) + ee $=$ gren.gee $($ importance $)$

$\mid \gamma \rho \mathrm{IN} \gamma / \quad / \mathrm{l} \backslash / \gamma \rho \mathrm{I} / \mathrm{\gamma} \cdot \mathrm{l} /$

They are counter parted in vain

Through syllabifying these examples and following the Kurdish phonological rule, we can see that the combination of $(\mathrm{n}+\mathrm{g})$ produces two sounds which are $/ \mathrm{n} / \mathrm{and} / \mathrm{g} /$. One of them stays with the first syllable and the other one joins the second syllable with the added morpheme. From this we can say that this combination does not produce the velar nasal.

\subsection{Acoustic Analysis}

For the aim of the acoustic analysis, pairs of words with a possible occurrence of the velar nasal/ $\mathrm{N} /$ contrasted with words ending with $/ \mathrm{n} /$ (Appendix B) were presented for Kurdish native participants to be recorded. After analyzing the acoustics of the recordings using Praat, the following findings were discovered.

Since it is not possible to report all the analyses of all the recordings, the average finding of each of the pairs under contrast are reported in Appendix (C). They all confirm the previous arguments discussed in the articulatory analysis:

1) The first word in each pair (the one ending with/n/) has more nasal bands than the second which ends with /ng/.

2) The absence of the nasal bands and thus of formant structures at the end of the second is evidence for the existence of a plosive consonant.

\section{CONCLUSION}

We can conclude from both articulatory and acoustic analysis of the data that the velar nasal can be found in Badini Kurdish but only as an allophone of the alveolar nasal which is the result of certain phonological rules such as assimilation and coarticulation. They are in free variation and couldn't change the meaning. The acoustic analysis also supports the articulatory results. Final nasal bands were absent from our examples that had a possible chance for the occurrence of the velar nasal. This suggests the absence of minimal pairs that differ in $/ \mathrm{n} /$ and /N/. So, we can't consider/N/ as a distinct phoneme in this dialect but rather as an allophonic realization of the sound $/ \mathrm{n} /$.

\section{REFERENCES}

Al-Bamerni, A. A. (2004). A study of the pronunciation of Iraqi announcers of news in English.Unpublished doctoral dissertation.University of Mosul.

Ali, B. O. (2007). The /N/ Phoneme in Sulaimany Dialect. (in Kurdish). SulaimanyUniversity Magazine B. No.19. Pp. 3946.

Ameen. N. A. (1982). Kurdish Writing problems with reference to vowels and consonant (in Kurdish).The jornal of the Iraqi Academy, Kurdish corporation.Vol. 9. Baghdad: Iraqi assembly press. Pp. 360-419.

Ameen W. O. (2004). Another level of linguistics.(In Kurdish).Hawler: Aras publisher

Anderson (2008) G. D. S. Areal and phonotactic distribution of /N/.MpI-EVA/Leipzig.Retrieved from http://www.livingtongues.org/docs/Velar_nasal.pdf in 23/6/2016

Azadpour H. \&Mohammadi M. (2014).A comaparative study of the phonological systems of Kurdish varaieties. Journal of Language and Culture Education: Slovak Edu.

Baban Sh. (2005).Phonetics and syllabification in Kurdish syntax.(In Kurdish).Hawler: Kurdistan Information Assembly.

Blevins, J. (1996). The syllable in phonological theory. In J. Goldsmith (Ed.), The handbook of phonological theory.Oxford: Blackwell. Pp. 206-244.

Fatah, M. M. (1982).Kurdish orthography in the lights of phonetics (in Kurdish).The jornal of the Iraqi Academy, Kurdish corporation.Vol. 9. Baghdad: Iraqi assembly press. Pp. 229267.

Gimson, A. C. (1970). An introduction to the pronunciation of English. (2nd ed.). London: Arnold.

Hawramany M. A. (1981). Kurdish language dialects in contrast.(In Kurdish). Baghdad: Ministry of Culture and Media.

Mackenzie D. N. (1961). Kurdish dialect studies-I. London: Oxford University Press

Marif A. H. (1976). Kurdish in the light of phonetics. (in Kurdish). Baghdad: Kurdish information assembly.

Thackston W. M. (2006). Kurmanji Kurdish: A reference grammar with selected readings. Retrieved fromhttps://www.fas.harvard.edu/ iranian/Kurmanji/kurman ji 1 grammar.pdf in23/6/2016

WaisGh. F. (1984). Phonetics.(In Kurdish). Baghdad: Al-Adib Press.

The official website of the Kurdish Academy of Language. (2017)http://www.kurdishacademy.org/?q=node/119 
Appendix A

List of words having $/ \mathrm{n} /$ preceeding $/ \mathrm{g} /$ with possible occurrence of $/ \mathrm{N} /$ Kurdish words IPA Symbols Meaning in English

$\begin{array}{ccc}\text { dang } & / \delta \Theta N \gamma / & \text { (sound) } \\ \text { bang } & / \beta \alpha\rceil \mathrm{N} \gamma / & \text { (call) } \\ \text { tang } & / \tau \geq \Theta N \gamma / & \text { (tight) } \\ \text { ding } & / \delta\rceil \mathrm{N} \gamma / & \text { (fat) } \\ \text { sting } & / \sigma \tau \mathrm{I} \gamma / & \text { (stinger) } \\ \text { mang } & / \mu \alpha\rceil \mathrm{N} \gamma / & \text { (month) } \\ \text { dang } & / \delta \alpha\rceil \mathrm{N} \gamma / & \text { (bottom) } \\ \text { rang } & / \rho \Theta \mathrm{N} \gamma / & \text { (color) } \\ \text { jang } & / \delta \mathrm{Z} \Theta \mathrm{N} \gamma / & \text { (war) } \\ \text { parang } & / \pi \Theta \rho \Theta \mathrm{N} \gamma / \text { (ember) } \\ \text { ahang } & / \alpha\rceil \eta \Theta \mathrm{N} \gamma / & \text { (party) } \\ \text { drang } & / \mathrm{dr} \Theta \mathrm{N} \gamma / & \text { (late) } \\ \text { greng } & \mid \gamma \rho \mathrm{N} \gamma / & \text { (important) } \\ \text { farhang } & / \phi \Theta \rho \eta \Theta N \gamma / & \text { (dictionary) } \\ \text { chalang } & / \tau \Sigma \Theta \lambda \Theta \mathrm{N} \gamma / & \text { (brave) } \\ \text { ping } & / \pi \mathrm{IN} \gamma / & \text { (peppermint) } \\ \text { pling } & / \pi \geq \lambda \mathrm{IN} \gamma / & \text { (tiger) } \\ \text { barTang } & / \beta \Theta \rho \tau \geq \Theta \mathrm{N} \gamma / & \text { (limited) } \\ \text { sang } & / \sigma \geq \mathrm{N} \gamma / & \text { (weight) } \\ \text { zang } & / \zeta \Theta N \gamma / & \text { (ring) } \\ \text { leng } & \mid \lambda \mathrm{IN} \gamma / & \text { (leg) } \\ \text { sing } & / \sigma \mathrm{IN} \gamma / & \text { (chest) } \\ \text { chang } & / \tau \Sigma \Theta N \gamma / & \text { (wing) }\end{array}$

Appendix B

List of pairs having / $/ \mathbf{n}$ contrasted with /n/ preceeding /g/ with possible occurrence of $/ \mathrm{N} /$

\begin{tabular}{|c|c|}
\hline dan & dang \\
\hline$/ \delta \Theta v /$ & $/ \delta \Theta N \gamma /$ \\
\hline ban & bang \\
\hline$/ \beta \alpha\rceil_{v} /$ & $/ \beta \alpha\rceil \mathrm{N} \gamma /$ \\
\hline (roof) & (call) \\
\hline $\tan$ & Tang \\
\hline$/ \tau \geq \Theta v /$ & $\mid \tau \geq \Theta N \gamma /$ \\
\hline (ton) & (tight) \\
\hline stin & sting \\
\hline$/ \sigma \tau \imath\rceil_{v} /$ & $/ \sigma \tau \mathrm{I} v \gamma /$ \\
\hline (pillar) & (stinger) \\
\hline Chin & ching \\
\hline $\left.\mid \tau \Sigma_{1}\right\rceil_{\nu} /$ & $\mid \tau \Sigma \mathrm{IN} \gamma /$ \\
\hline (China) & (Children's game ) \\
\hline $\operatorname{man}$ & mang \\
\hline$/ \mu \alpha\rceil v /$ & $/ \mu \alpha\rceil \mathrm{N} \gamma /$ \\
\hline (staying) & (month) \\
\hline $\operatorname{din}$ & ding \\
\hline $\begin{array}{l}\delta \mathrm{\delta} / \mathrm{v} / \\
\text { (crazy) }\end{array}$ & $\begin{array}{c}\delta \mathrm{\delta IN \gamma /} \\
\text { (fat) }\end{array}$ \\
\hline
\end{tabular}

Appendix C

Acoustics of List of pairs having /n/ contrasted with /n/ preceding /g/ with possible occurrence of $\square \square \square$

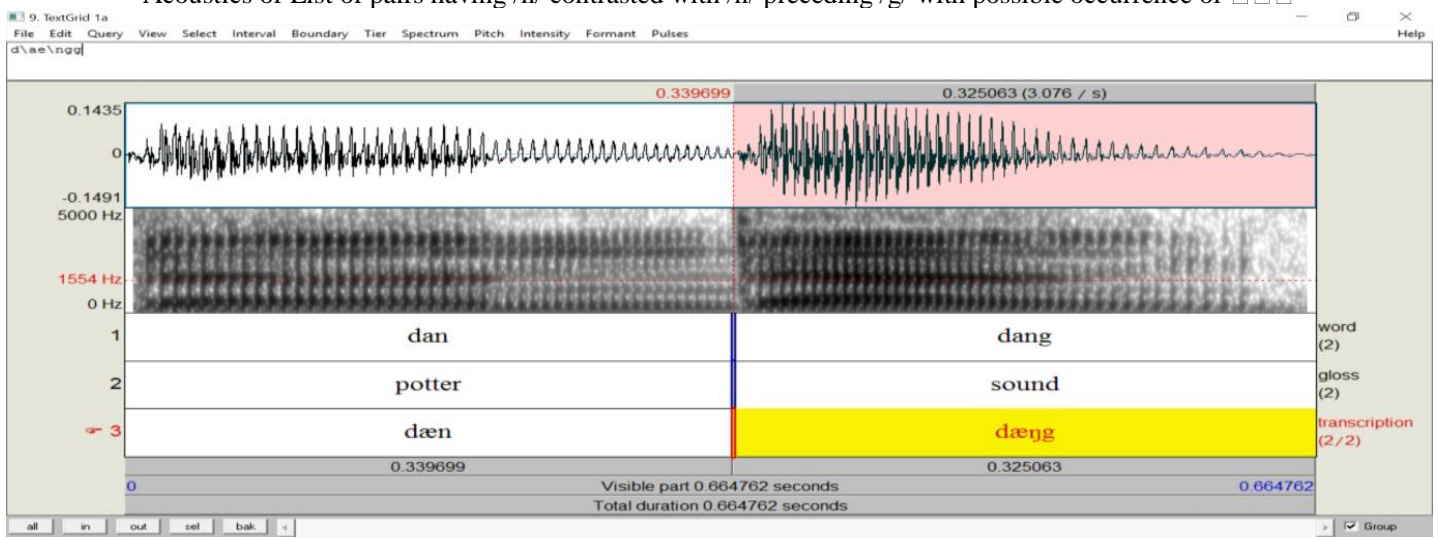


Figure 1. the contrast between the pair (dan) and (dang) in Praat.

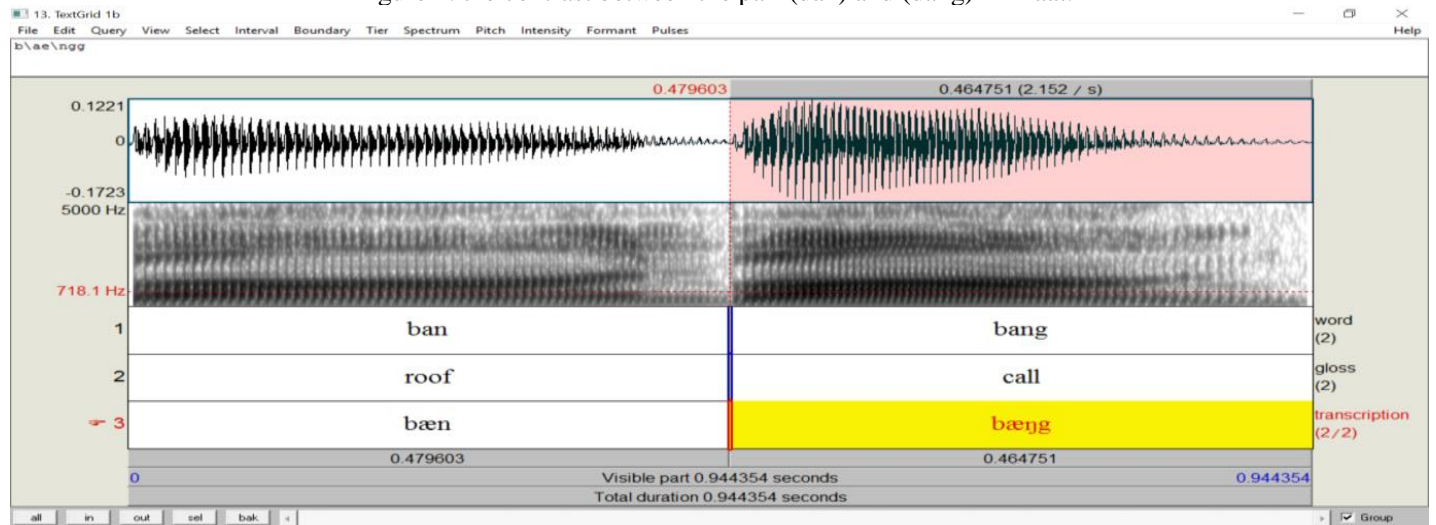

Figure 2. the contrast between the pair (ban) and (bang) in Praat.

T. T. TextGrid $1 \mathrm{c}$

File Edit Query View Select Interval Boundary Tier Spectrum Pitch Intensity Formant Pulses

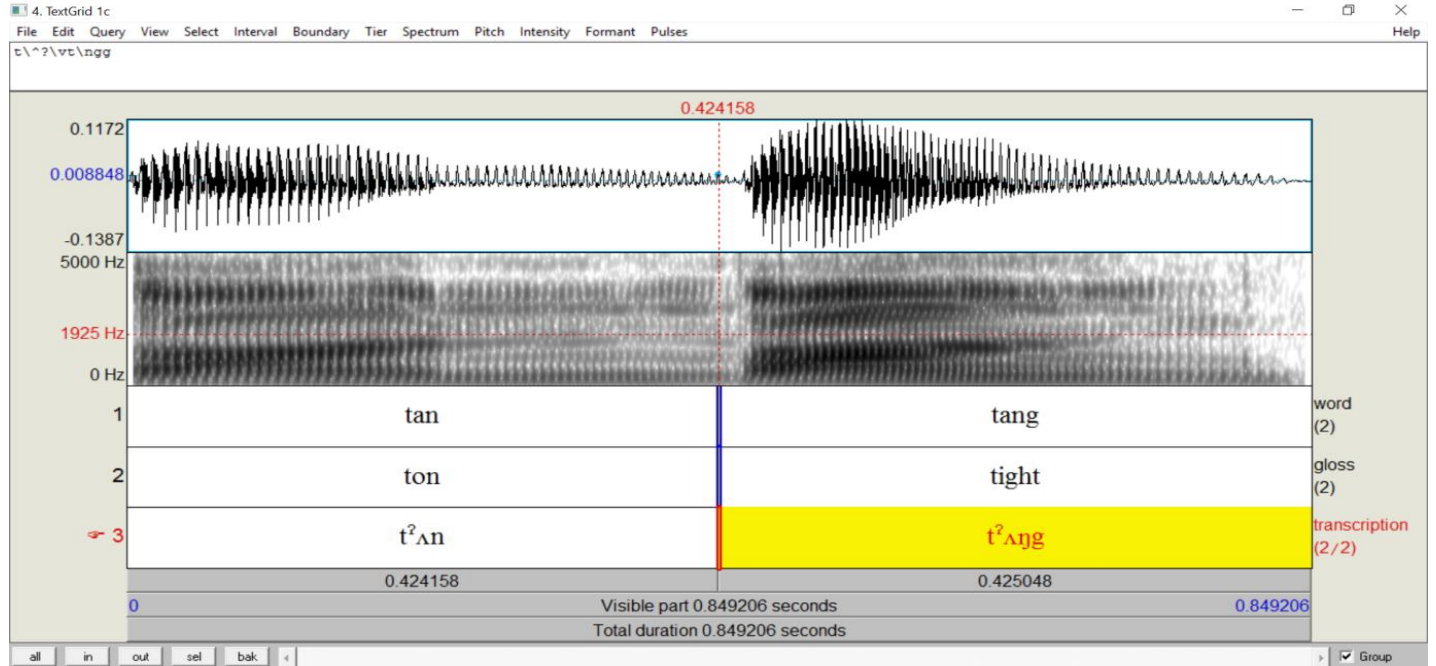

Figure 3. the contrast between the pair (tan) and (tang) in Praat.

2] 18. TextGrid $1 \mathrm{~d}$

\begin{tabular}{l} 
Fi 18. TextGrid 1d \\
File Edit Query View Select Interval Boundary Tier Spectrum Pitch Intensity formant Pulses \\
\hline di1: $\backslash \backslash$ ngg
\end{tabular}

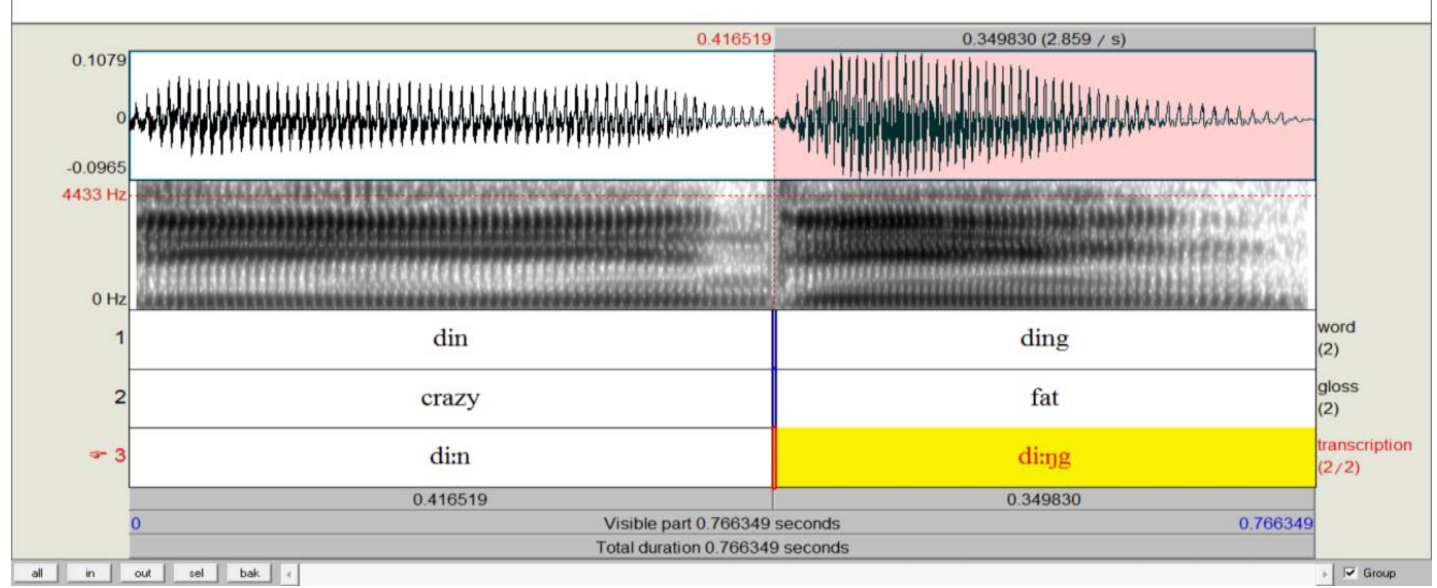

Figure 4. the contrast between the pair (din) and (ding) in Praat. 
211 30. TextGrid 1e

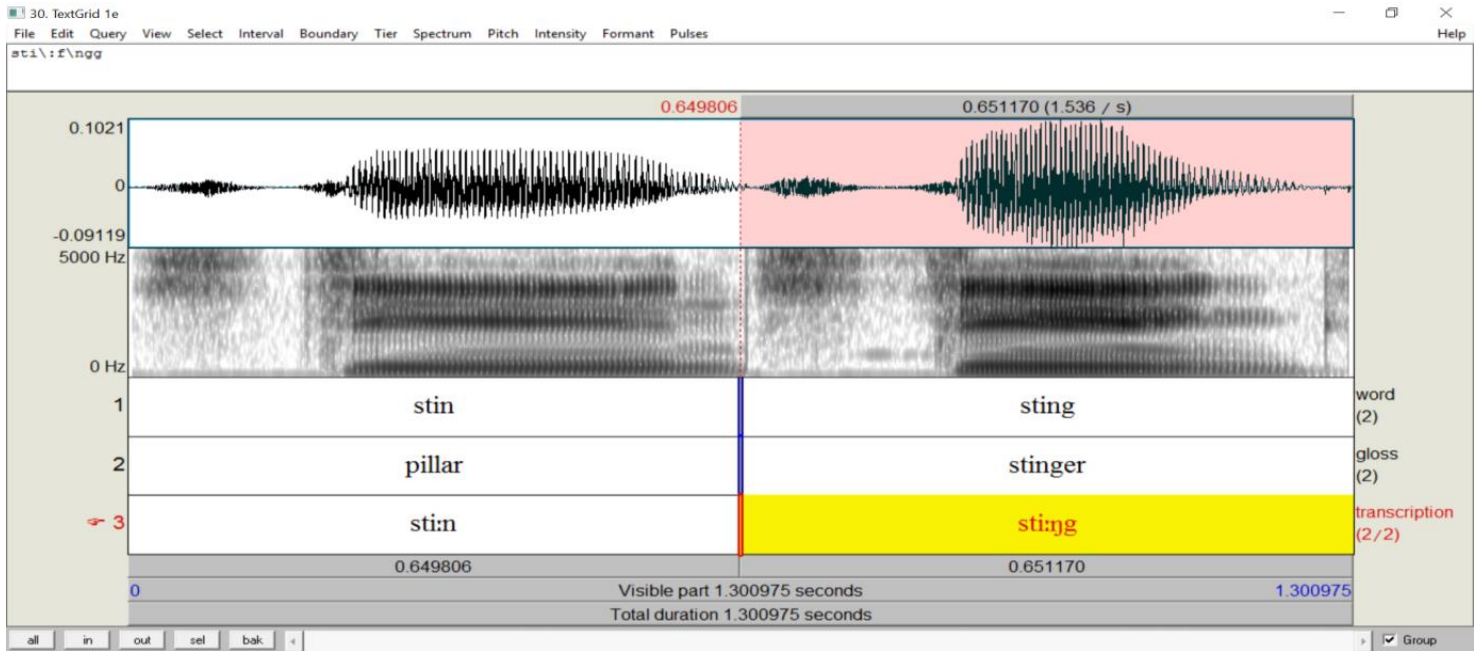

Figure 5. the contrast between the pair (stin) and (sting) in Praat.

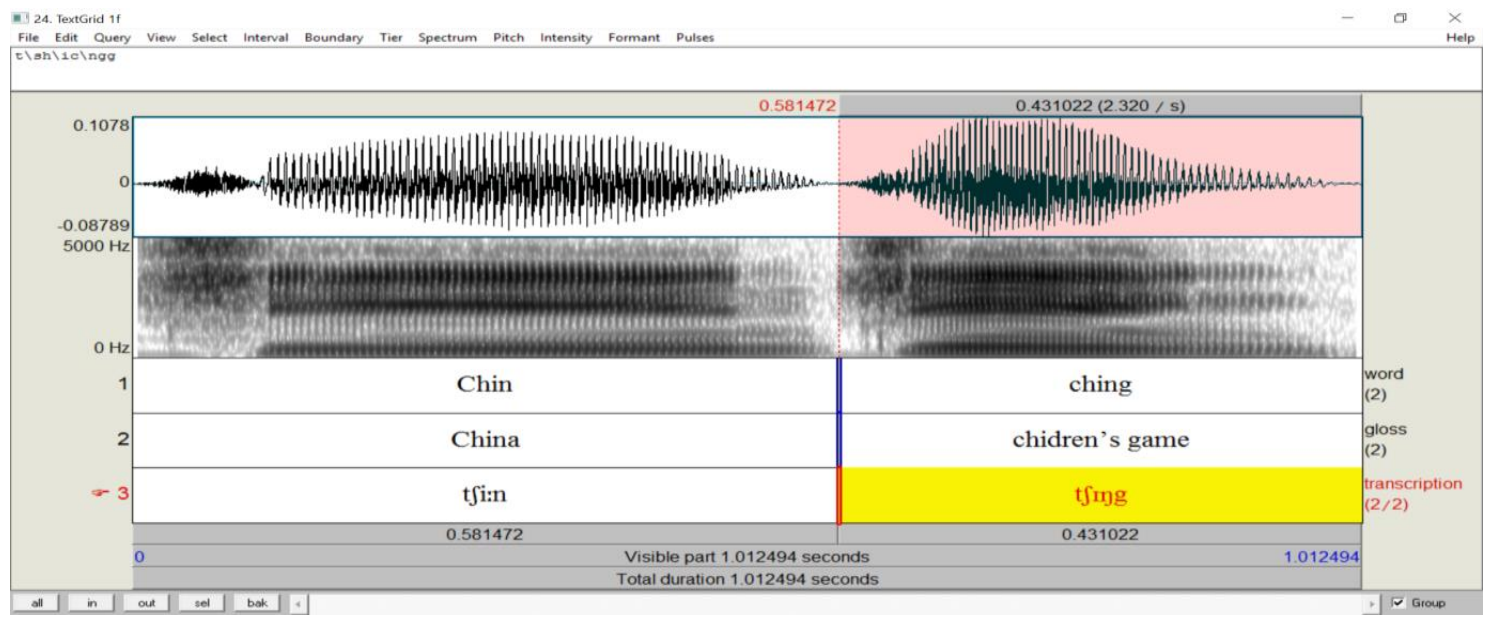

Figure 6. the contrast between the pair (chin) and (ching) in Praat.

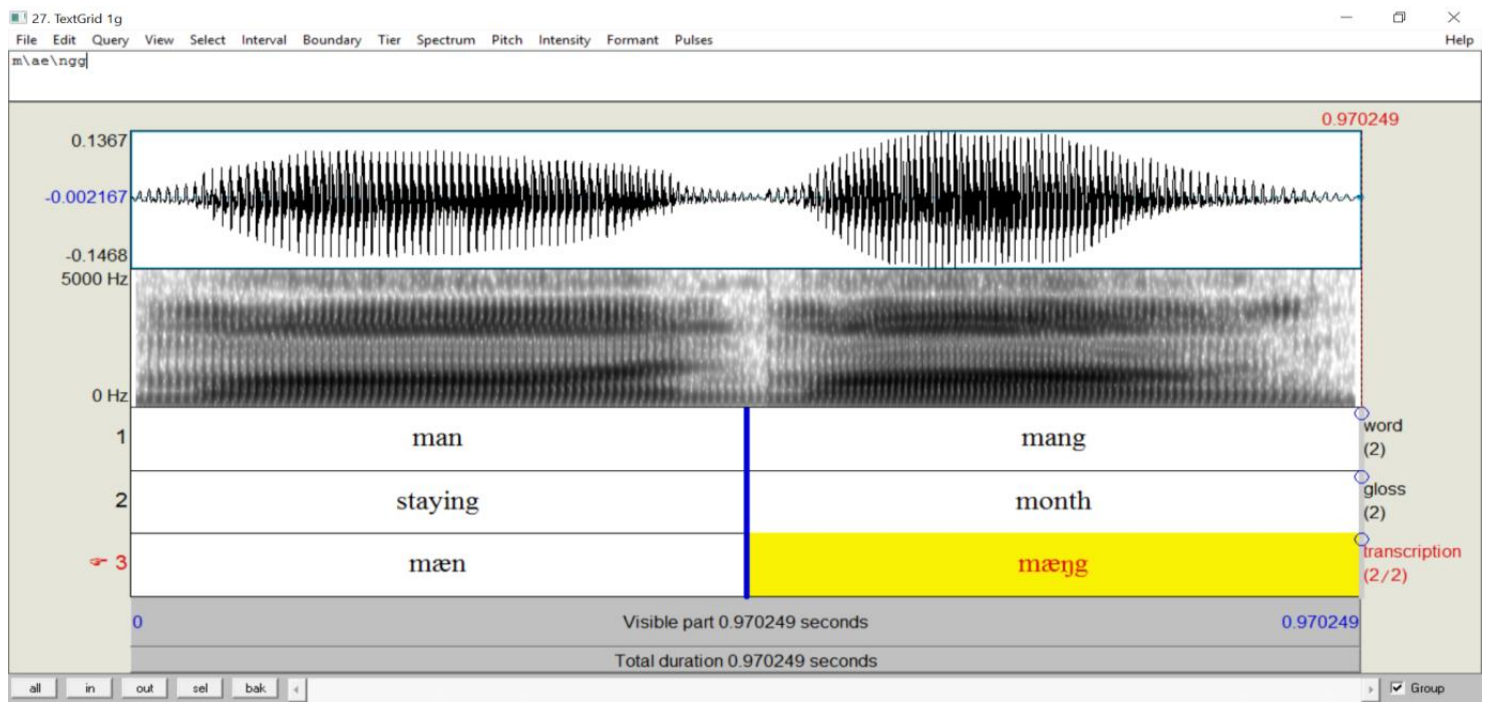

Figure 7. the contrast between the pair (man) and (mang) in Praat. 


\section{نيرينهك د دهنگى يهحنكيّى دفنى دا د دياليكتا كورديا بادينى دا}

فونبمى به حنكيّى دفنى دهيته ديتن دليستا فونيمين گهلهك زمانا ل جيهانى ـ ثهكوله رين كورد بوجونين جودا ههنه ل دور ههبونا ثى دهنكى دليستا فونيمين

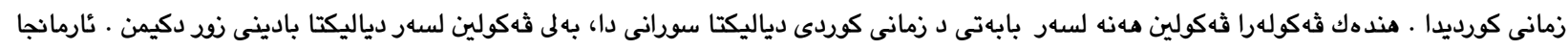

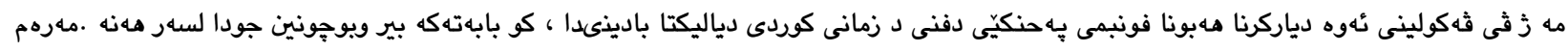

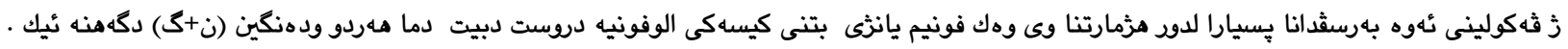

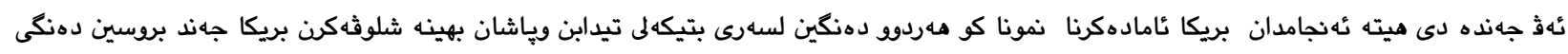

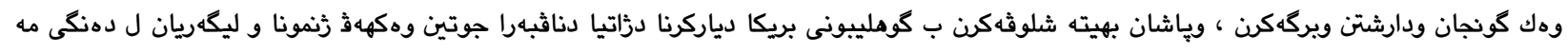

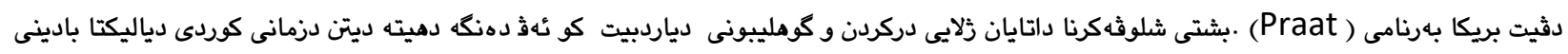

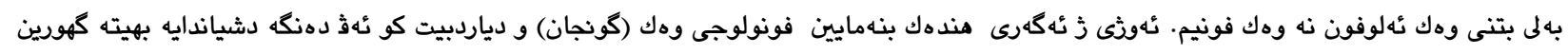

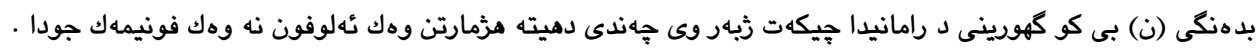

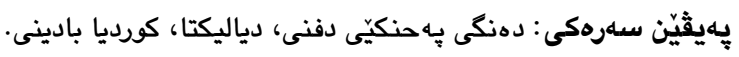

\section{استقصاء في صوت الطبقي الانفي في اللهجة الكوردية البادينية}

الملخص: يمكن العثور على صوت الطبقي الأنفي في قائمة فونيمات العديد من اللغات في مختلف أنحاء العالم . يختلف الباحثون الكورد في أرائهم حول ما إذا كان الصوت

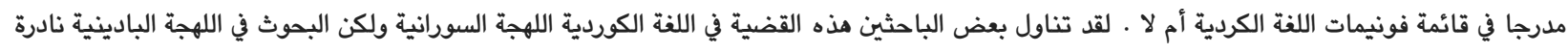

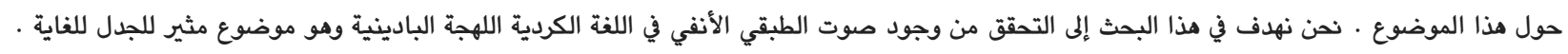

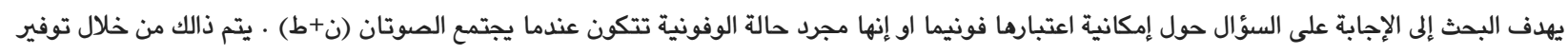

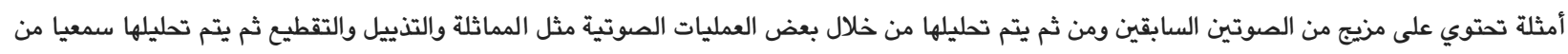
خلال إظهار التناقض بين الأزواج المتماثلة من الأمثلة والبحث عن الصوت المنشود باستخدام برنامج ( Praat) . بعد تحلئ تحليل كل البيانات المفصلية والصوتية

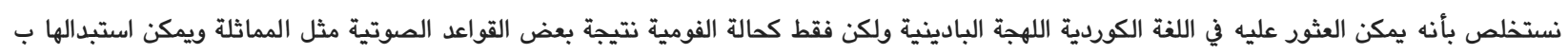

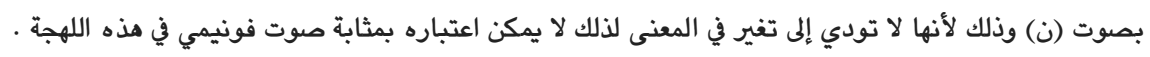

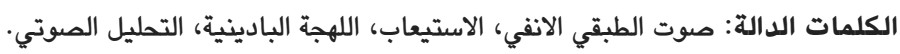

